\title{
Analysis of Rice Supply Chain in Kenya
}

\author{
Johnmark Obura ${ }^{1}$, Benjamin O. Ombok ${ }^{2}$, Gordon Omugah ${ }^{1}$ \\ ${ }^{1}$ Department of Management Science, Maseno University, Kenya \\ ${ }^{2}$ Department of Accounting and Finance, Maseno University, Kenya
}

\begin{abstract}
In the last decade, supply chain management has played an important role in leading organizations today to; succeed in their business goals, gain competitive advantages, and improve business performance. As the result of that, most scholars have extensively and repeatedly studied a topical issue in strategic supply chain management with the objective of improving business performance in ideal situation. This is because the uncertain factors in current business world, are crucial in both supply and demand sides to influence many companies to continuously work on adopting proper value chains in their organizations. However, there has been little effort to unmask the impact of these uncertain factors that cause inefficiency in the supply chains especially on particular food supply chain that is NCPB rice supply chain in a conceptual framework. This study is a critical analysis of literature to develop the conceptual framework that is proposed to analyze the relationship among uncertain factors, rice supply chain practices, and rice supply chain performance as well as to discuss research methodology.
\end{abstract}

Keywords: NCPB-National Cereals and Produce Board, Supply Chain Management and National Irrigation Board.

\section{INTRODUCTION}

Staple food supply chain has been the top in the government budgeting since the threat of death toll has been on the rise due to lack of food in some regions of Kenya. (Daily Nation 27 January 2017). Northern part of the country has been a victim several times with the highest number of lives lost due to starvation yet the country has the capacity to produce enough food. (Kenya Food Security Steering Group, 2008).

Since the colonial government, NCPB has been the leading agricultural commodity management and trading organization in East \& Central Africa. The supply of agricultural grain products have been better and complementary. This has recently been compromised by delay to take reforms and match the ever growing population of the country that is at $2.6 \%$ annually. (KBS, 2015). Specifically, the third most common food, rice supply chain has been on the look since most people are not aware of the locally processed and packed rice which is equally affordable and available in the local stores. e.g. Nafaka, Nerica, Pishori and Pure Aromatic rice among others. (Kenya grain and feed annual, 2016).

With the current situation of high population growth, it in notable that the food supply in the country will always be a problem if nothing is done to make good use of the available alternative source of grain food. The aim of this research therefore is to propose a better supply chain to be implemented to ensure there is effective collection of paddy, processing and distribution to reduce the level of food shortage in the country by making the local rice processing and distribution effective enough to reach the level of village shops at affordable rates.

\section{LITERATURE REVIEW}

\subsection{Rice Typology in Kenya}

In Kenya rice is mainly produced by small-scale farmers in Central (Mwea), Western (Bunyala), Coast (Tana delta, Msambweni) and Nyanza provinces (Ahero, West Kano, Migori and Kuria). About 300,000 rice farmers provide labour and also earn their livelihood out of the crop's production. There are four major rice mills spread across the country with varying capacities. LBDA has a milling capacity of 3.5 metric tons, Mwea NIB 24 metric tons, Western Kenya Rice mills 3 metric tons and Tana Delta with 3 metric tons per hour. Additionally there are several small privately owned one pass 
mills especially in Mwea. There are several rice traders in the country. The major traders include the government owned National Cereals and Produce Board (NCPB), National Irrigation Board (NIB) and Lake Basin Development Authority (LBDA) through their rice mills in Ahero, Mwea and Kibos process and supply milled rice to supermarkets and local retailers; Mwea Farmers' Multipurpose Cooperative Society, Supermarkets in major urban centers, Dominion Farms and Capwell Industries among others. In addition, there are also numerous small traders mostly women who sell rice in the local markets.

\subsection{Rice Supply Chain}

Supply chain encompasses all of those activities associated with moving and transforming inputs (goods) from the raw-materials stage through to the end user (Harrison \& Van 2011). To ensure corporate survival, enterprises have to compete globally by consolidating supply chain members and maximizing the end-product value of the supply chain (Ming \& Hsin 2006). NCPB has been on the spotlight with many intermediaries that end up opening their own firms to compete their employer. The cartels that are also managed by the employees of the board have the information about the whole process and therefore takes the advantage of the links they have with the paddy rice farmers who want quick money at the point of rice harvest.

Many scholars have believed that the whole supply chain should be taken as a virtual entity (G, Juanqiong 2007). Based on these characteristics, this study builds up a process of strategic rice supply chain management (SRSCM) that comprises three main stages: paddy collection, processing and distribution. NCPB rice processing has been working out on how to ensure that the staple food is delivered to the citizens right on time. The supply chain study suggest that it would be beneficial for the government to move from its present production focus, towards a more 'whole-chain' focus (Joni, 2010). This therefore needs re-structuring of rice supply chain.

The supply chain model in play is the very traditional that was set by the Asians who introduced rice farming in Kenya in 1907. (Rice Sector Development, 2012). This has held captive the improvement to the rice supply chain in the country since operations in supply chain cannot be accommodated with the current technology which is digital and fast. Fear for the unknown has also been the trending reason as to avoid implementation of new automated supply chain that can improve the circulation of rice. (Emma 2012), where the NCPB are not ready to implement the strategies that will ensure the system is automate fully. Organizations that have positive physiological contracts with their staff re rewarded with high levels of employee commitment. This normally translates into high performance (Richard \& David 2014).

\subsection{Paddy Rice Collection and Distribution of Rice}

Rice in Kenya is mainly grown in irrigation schemes that are managed by the state-owned National Irrigation Board (NIB). In addition to the irrigated Basmati rice, the GOK and county governments are promoting production New Rice for Africa (NERICA), an improved, rain-fed, upland rice variety. The NIB has also been rehabilitating and expanding the existing irrigation schemes, and the area under rice has increased gradually (NIB 2015).

Rice consumption in Kenya continues to increase rapidly due population growth, changing dietary preferences, higher incomes and urbanization. Consumption growth is estimated at 11 percent per year and the supply deficit is met by imports from Pakistan, Vietnam, Thailand, and India. There are also minimal imports from neighboring EAC countries. Effective July 1, 2015, EAC common external tariff of 75 percent ad valorem or $\$ 345$ USD per ton (whichever is higher), is applicable to rice imports from non-EAC countries. Kenya was however granted a one year extension of "the stay of application", based on limited local production, and therefore continues to apply the 35 percent advalorem or \$200 USD per ton (whichever is higher), tariff structure. This waiver is reviewed every year by the EAC secretariat.

Harsh climatic conditions have since been a major threat to rice production. It has posed a challenging situation to Kenan rice farmers and for occasionally interfered with the production of paddy rice. Most farmers lack incentives to subsidize the overhead costs incurred in farms. NCPB is therefore facing a situation whereby the projections for rice yields is not met in most occasions. (Emmy \& Faith, (2007). The overall rainfall distribution in the country is not reliable and the country has continued to experience food deficit necessitating importation of critical agricultural commodities like rice (Thairu, 2010). 


\subsection{Rice Marketing}

The opportunity in display for the rice consumption is massive. Most Kenyans living in the rural areas consume limited quantities of rice, but it forms an important diet for the majority of urban dwellers. The annual consumption is increasing at a rate of $12 \%$ as compared to $4 \%$ for wheat and $1 \%$ maize, which is the main staple food. This is attributed to progressive change in eating habits. The national rice consumption is estimated at 300,000 metric tons compared to an annual production range of 45,000 to 80,000 metric tons. The deficit is met through imports which are valued at KSHS 7 billion in 2008. Promotion of rice production through the use of an efficient supply chain will therefore improve food security, increase smallholder farmers' income contribute to employment creation in rural areas and reduce the rice import bill.

\subsection{Agency Theory}

It is a critical task for managers in the NCPB to understand and mitigate abnormal behaviors across the supply chain of rice production and distribution. Agency theory serves this need by providing them with a useful tool to respond to transaction cost dilemmas through contractual and non- contractual remedies (Plambeck 2010). In his work he explains that, despite agency theory's prevailing descriptive and predictive qualities there is scarcity in its application to the SCM discipline in the management, for this case - NCPB. The theory therefore provides valuable insights for relationship engineering within supply chains where social, political, legal and behavioral dynamics dominate.

\section{Methodology}

\section{Data Collection}

Considering the past researches, the appropriate data source used here is secondary. To explore this field explicitly, the study adopted a meta-analysis research design for they portrayed an accurate profile of situations. (Andrews 2012). Meta-analysis refers to the analysis of analyses... the statistical analysis of a large collection of analysis results from individual studies for the purpose of integrating the findings (John 2003). According to the NIB, the amount of rice produced continues to increase with increase in size of irrigated lands. (NIB 2016). The study used the data to analyze the need to restructure the rice supply chain in the country.

The data size used in previous researches mostly fall in the range of $66-70$ in population. This size is perceived to be very limited as the size is too small and may not give the correct information when not well cleaned and studied. The study therefore agree with the size used by Emmy 2016 where sample size of 100 is credited for better results.

The study area was NCPB Headquarter with a broad view of the whole rice supply chain in Kenya. It is noted that, the board has over 1000 employees who are mandated to ensure success in the rice milling and distribution to various outlets. The secondary data collected was studied and used to get a clear understanding of the whole process.

\section{ReSUlts AND DiscusSiOnS}

Figure1. Kenyan population

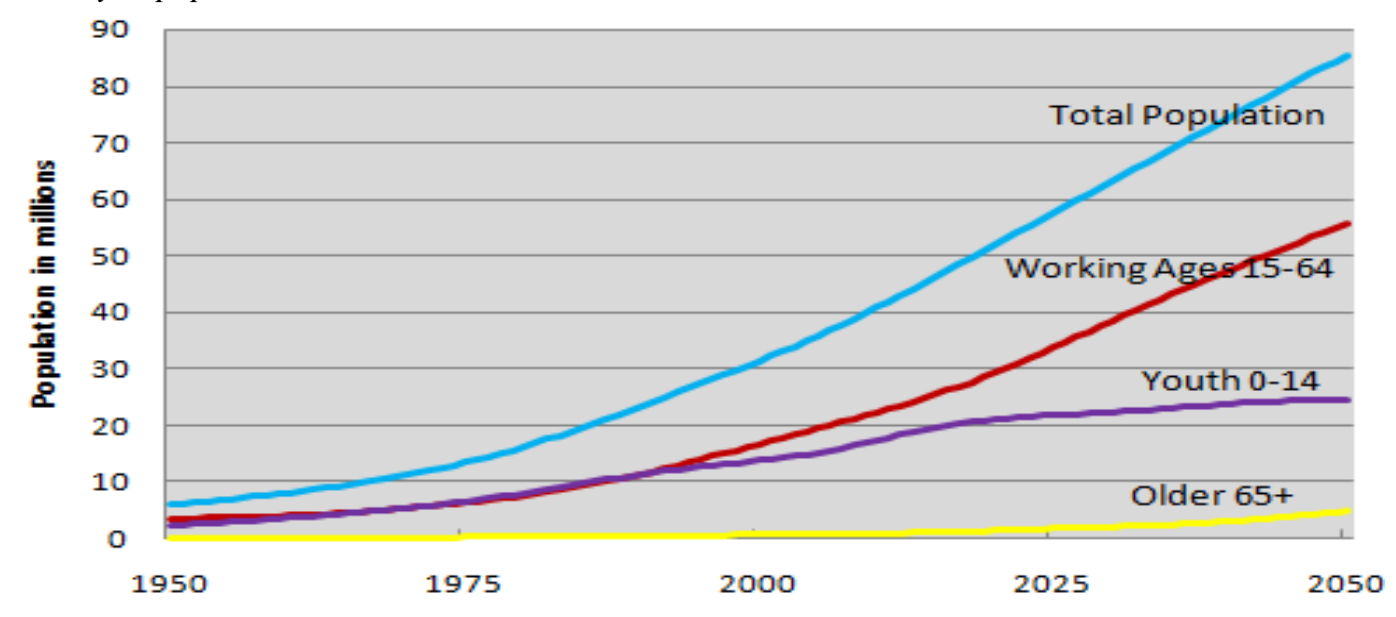

Source: Kenya Bureau of statistics (2017) 
The positive growth of the country's population is observed in the last decades. This continuous increase in the population translates to more resources required to sustain the good health especially in the food supply. The more the people the higher the rate of consumption.

Table1. Noted challenges faced by the Board

\begin{tabular}{|l|l|l|l|l|}
\hline Parameter & Frequency & Percent & Valid percent & Cumulative percent \\
\hline Marketing & 6 & 6.0 & 6.0 & 6.0 \\
\hline Delayed payments & 32 & 32.0 & 32.0 & 38.8 \\
\hline Transportation & 6 & 6.0 & 6.0 & 44.0 \\
\hline Information access & 26 & 26.0 & 26.0 & 70.0 \\
\hline Insufficient water & 18 & 18.0 & 18.0 & 88.0 \\
\hline Lack of credit facility & 12 & 12.0 & 12.0 & 100.0 \\
\hline Total & $\mathbf{1 0 0}$ & $\mathbf{1 0 0 . 0}$ & $\mathbf{1 0 0 . 0}$ & \\
\hline
\end{tabular}

Source: Emmy Kisang 2016

From the data collected and analyzed, it is evident that there are a number of factors that contribute to the poor performance of the supply chain of rice in Kenya. Above the chart of the parameters are; delayed payments, information access, water for irrigation and finance (credit facility). In this case, the board is still not able to access enough information from supply chain consultants with diverse information on the management of supplies and the logistics. It is evident that marketing is also among the issues that needs to be addressed to ensure that the board secures larger market share for their cereals, rice being the main target.

Table2. Current rice production and rice projections based on area, yield and consumption in 2008 by Agroecological condition

\begin{tabular}{|c|c|c|c|c|c|c|c|c|c|c|c|c|}
\hline \multirow[t]{2}{*}{ Year } & \multicolumn{3}{|c|}{ Rain fed upland } & \multicolumn{3}{|c|}{ Rain fed lowland } & \multicolumn{3}{|c|}{ Irrigated } & \multicolumn{3}{|l|}{ Total } \\
\hline & \begin{tabular}{|l|} 
Area \\
$(\mathrm{Ha})$
\end{tabular} & $\begin{array}{l}\text { Yield } \\
\text { (tons/ha) }\end{array}$ & $\begin{array}{l}\text { Prod } \\
(\mathrm{Ha})\end{array}$ & $\begin{array}{l}\text { Area } \\
(\mathrm{Ha})\end{array}$ & $\begin{array}{l}\text { Yield } \\
\text { (tons/ha) }\end{array}$ & $\begin{array}{l}\text { Prod } \\
(\mathrm{Ha})\end{array}$ & $\begin{array}{l}\text { Area } \\
(\mathrm{Ha})\end{array}$ & $\begin{array}{l}\text { Yield } \\
\text { (tons/ha) }\end{array}$ & $\begin{array}{l}\text { Prod } \\
(\mathrm{Ha})\end{array}$ & $\begin{array}{l}\text { Area } \\
(\mathrm{Ha})\end{array}$ & \begin{tabular}{|l} 
Yield \\
(tons/ha)
\end{tabular} & $\begin{array}{l}\text { Prod } \\
(\mathrm{Ha})\end{array}$ \\
\hline 08 & 2,150 & 2.72 & 5,851 & 3,180 & 2.76 & 12,500 & 12,500 & 4.7 & & 17,830 & 4.1 & 141 \\
\hline & & 3. & & & 3.20 & & & J & & & 14 & \\
\hline 2018 & 4,100 & 3.70 & 14,800 & 5,050 & 3.76 & 18,180 & 26,000 & 5.6 & 145,600 & 35,150 & 5.1 & 178,580 \\
\hline
\end{tabular}

Source: $N C P B 2015$

From the output of the data collected in NCPB and NIB, it is crystal clear that the trends for rice production is on consistence increase. This translates to consumption due to increase in population who find it expensive to buy maize flour. It is also noted that; that the population is increasing at a very higher rate $(2.6 \%)$ annually posing a larger number of households who depend on the domestic food for their daily bread. This persistent increase in population and taste for rice has been noted in the years $2014-2016$ respectively.

Land tenure system in the rice growing schemes is also not favorable to farmers as they do not own land titles making it impossible to access credit. On the other hand women are key players in rice production, but yet they do not own land. For sustainable rice production, the land tenure system need to be addressed to provide for ownership and to allow women access to land and more MT of rice will be harvested and milled locally to avoid deficit.

Figure2. The stakeholders in rice SC

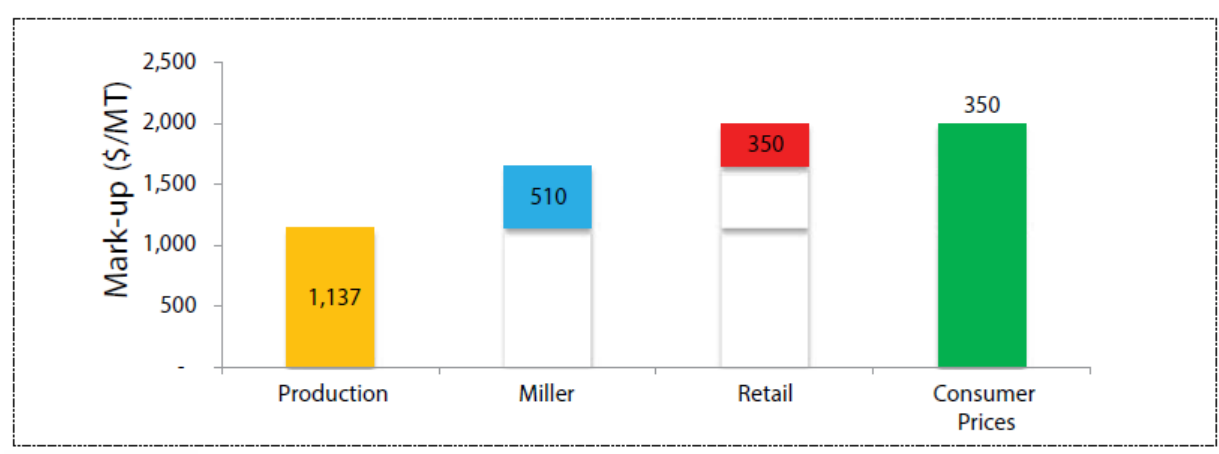

Ideal Rice supply chain (Mwea Irrigation Scheme) 
Source (NCPB 2015)

From the data, there are a lot of costs incurred by the consumer of rice who buys it from the third party. In this case, there is a possibility to remove retailers to ensure that rice is sold to the citizens at a reduced rate. NCPB is the government miller of rice and is selling at 510 more. This also translates to further additional 530 by retailer who transfers the whole costs to the consumers. This has not been noted in previous research with a recommendation to reduce the number of intermediaries partnered with.

\section{CONCLUSION AND RECOMMENDATIONS}

\section{Restructuring the Rice Supply Chain of Rice at NCPB}

Figure3. Rice supply chain.

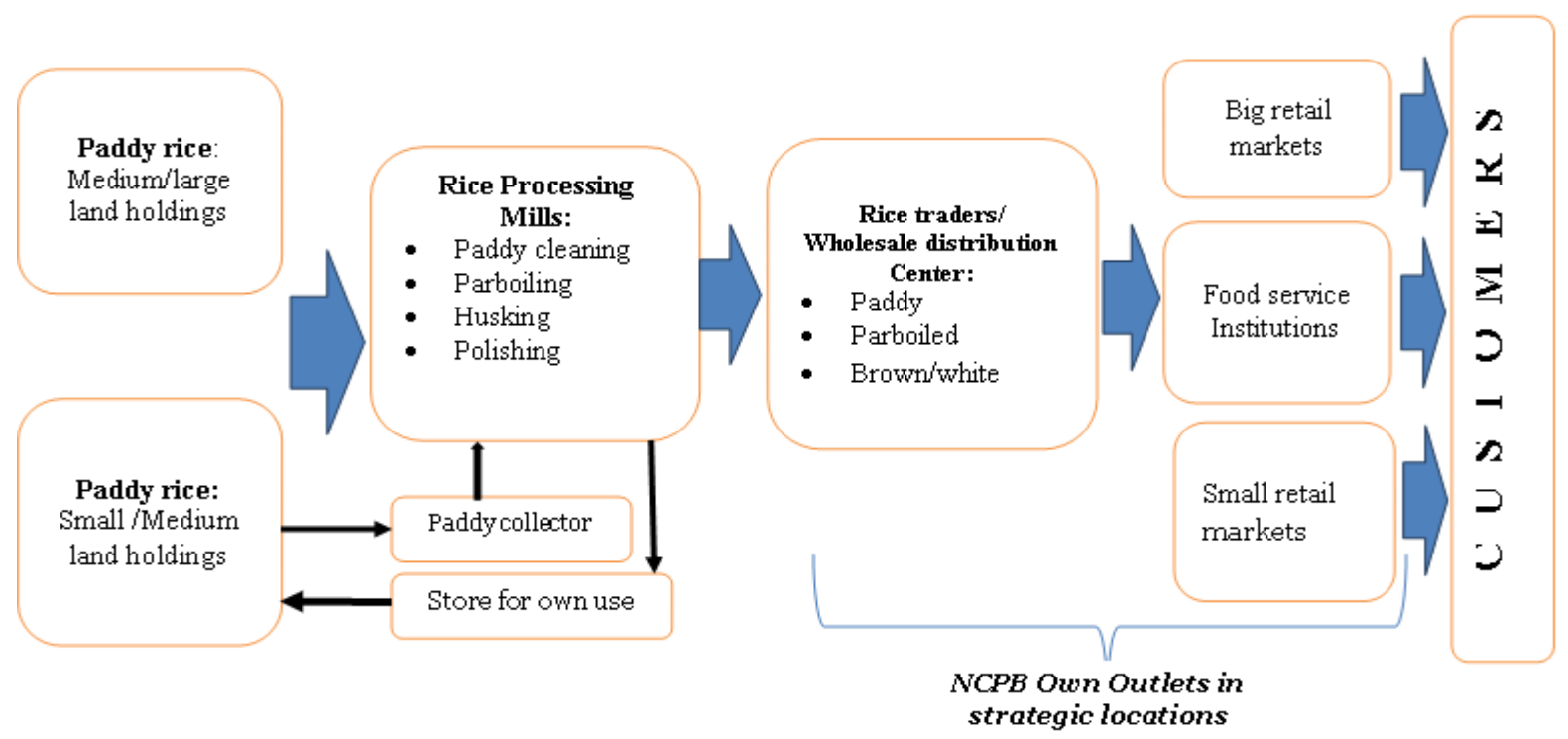

Source: (Adopted from rice supply chain -Srilanka). Figure of the detailed rice supply chain process suggested to be used by (NCPB - 2017)

From the related studies analyzed, it is viable to implement the above outlined model for the best and more responsive supply chain at NCPB to easy the management in the value chain in Kenya. Where there is an inter-related and collaborative sections all working to ensure rice is delivered to customers in time.

The current state of food insecurity in Kenya has for long been ignored until when maize prices escalated beyond the expectations in the first four months of the year 2017. Among the best available alternative left is rice which is equally consumed by more people. This immediate need to serve food to the citizens has to be done by the government of the day and that is where rice becomes more valuable commodity that need a shorter supply chain with limited intermediaries. It is logical for NCPB to establish their own outlets in more strategic areas and towns. This will reduce the supply chain stakeholder thus reduced total costs.

In addition, it is important to note that rice will continue to play a vital role in food security in Kenya and that there is need to undertake value chain analysis in order to determine the gaps and develop interventions to address them. Additional efforts therefore need to be made to address challenges facing rice by increasing investments in research and development.

The government should create and establish a system for production and distribution of seed and supply the right qualities/quantities to farmers. This is not limited to the extension activities on technical guidance, seed production and distribution, awareness creation, facilitation and establishment of government outlets that needs urgent attention for increased rice production.

The existing schemes need to be expanded and empowered together with development of upland and wetland areas to secure more rice production areas in the country. The empowerment should as well capitalize on the farmers and their organizations to undertake production and marketing of rice. 
Proper post-harvest management is required to reduce losses and improve quality of rice supplied to the government millers.

Famers need sufficient financial support for technology development and dissemination/extension services, capacity building and provision of mobile mills. This is to ensure that there is farmers' capacity building to acquire current knowledge on seed and other technical inputs used to establish a sustainable production.

\section{REFFERENCES}

[1] A.M. Edward (2001), Supply chain strategies, capabilities, and performance, Transportation Journal.

[2] Andrews, L., Higgins, A., Andrews, M. W., \& Lalor, J. G. (2012). Classic grounded theory to analyse secondary data: Reality and reflections. The Grounded Theory Review, 11(1), 12- 26.

[3] Blanchard, David (2010), Supply Chain Management Best Practices 2nd Edition, John Wiley \& Sons

[4] Emma Bosire, UoN (2012). Factors influencing management of change in public sector organizations in Kenya.

[5] Emmy J Kisang and Faith J yatta, (2007); Factors Influencing Rice Production in Kenya's Irrigation Schemes: The Case of Mwea Irrigation Scheme.

[6] G, Juanqiong, M, Tingting, L, Jingjing (2007). A Research on Supply Chain Integration Strategy Based on Virtual Value Net. Springer Boston, (pp 887-891)

[7] John W. Creswell (2003). Research sedign; Qualitative and quantitative approaches.

[8] Joni Murti Mulyo Aji, March 2010, The University of Queensland; Improving Food Security through Supply Chain Management: A Study of Rice Supply Chains in Indonesia

[9] Ministry of Agriculture, 2010. Economic Review of Agriculture in Kenya 2010. Nairobi

[10] Ministry of Planning \& National Development. 2010 Economic Review. Government Printers. Nairobi

[11] Ming-Hon Hwang a,b and Hsin Rau (2006), Development of strategies for shortening supply chain and demand chain

[12] National Rice Development Strategy, 2008. Ministry of Agriculture, Kenya Nairobi

[13] National Bureu of Statistics 2016

[14] National Cereals and Produce Board 2015 - 2018

[15] Plambeck, L., Gibson, P. (2010), "Application of agency theory to collaborative supply chains", paper presented at the Oxford Business \& Economics Conference (OBEC), 28-30 June, Oxford,

[16] Richard Smith, David King, Ranjit Sindu and Dan Skelsey (2014). The effective change manager's Handbook.

[17] Thairu Nicholas K (2010) Agricultural Production and Irrigation management; The Case of Irrigated Rice

Citation: Johnmark, Obura et al. "Analysis of Rice Supply Chain in Kenya" International Journal of Managerial Studies and Research (IJMSR), vol5, no.8, 2017, pp.12-17.doi:http://dx.doi.org/10.20431/23490349.0508002.

Copyright: () 2017 Authors. This is an open-access article distributed under the terms of the Creative Commons Attribution License, which permits unrestricted use, distribution, and reproduction in any medium, provided the original author and source are credited. 